\title{
Analysis of Geometric Relation between Cerebral Contusion and Site of Impact in Traumatic Brain Injury Patients
}

\author{
Amira P. Karima, ${ }^{1}$ Muhammad Kusdiansah, ${ }^{2}$ Ahmad Faried, ${ }^{2}$ Muhammad Z. Arifin ${ }^{2}$ \\ ${ }^{1}$ Faculty of Medicine Universitas Padjadjaran, Indonesia, ${ }^{2}$ Department of Neurosurgery Faculty of Medicine \\ Universitas Padjadjaran/Dr. Hasan Sadikin General Hospital Bandung, Indonesia
}

\begin{abstract}
Cerebral contusion is found in $17-34 \%$ of traumatic brain injury (TBI) cases. The inertial and contact effects responsible for this injury makes the presence and location of contusion almost impossible to detect without appropriate imaging techniques. This study aimed to identify the geometric association between site of impact and cerebral contusion in patients with TBI. Data were collected retrospectively from Dr. Hasan Sadikin Hospital Bandung, Indonesia from January 2016-December 2017. TBI patients were scanned for diagnosis of cerebral contusion on the initial CT scan and the presence of soft tissue swelling as the site of impact. The locations were then geometrically classified into four groups; frontal, right temporoparietal, left temporoparietal, and occipital. Analysis was then performed using the multinomial logistic regression method with $\alpha=0.05$ and $95 \%$ confidence interval (CI). Right temporoparietal contusion was associated with contrecoup impact compared to frontal impact ( $p=0.008$, OR 6.8, 95\% CI: 1.6-28.7) and occipital impact ( $p=0.002$, OR 6.8, 95\% CI: 1.7-26.8) while left temporoparietal contusion was associated with contrecoup impact compared to frontal $(\mathrm{p}=0.006,0 \mathrm{R} 6.8,95 \%$ CI: 1.7-26.8) and occipital impact ( $\mathrm{p}=0.016$, OR 10, 95\% CI: 1.3-17) and with coup impacts compared to frontal impacts ( $p=0.025$, OR 5.3, 95\% CI: 1.2-23.3). It is concluded that temporal contusion has a statistically significant correlation with contrecoup impacts.
\end{abstract}

Key words: Cerebral contusion, computed tomography, impact injury, traumatic brain injury

\section{Hubungan Analisis Geometris antara Kontusi Serebral dan Lokasi Benturan pada Pasien Cedera Otak Traumatis}

\begin{abstract}
Abstrak
Kontusi serebral ditemukan pada 17-34\% kasus cedera otak traumatika (TBI). Efek inersia dan kontak yang bertanggung jawab untuk cedera ini membuat keberadaan dan lokasi benturan hampir mustahil untuk dideteksi tanpa teknik pencitraan yang tepat. Penelitian ini bertujuan untuk menemukan hubungan geometris antara kontusi serebral dan lokasi benturan yang terjadi pada pasien TBI. Data dikumpulkan secara retrospektif dari Rumah Sakit Dr. Hasan Sadikin Bandung, dari Januari 2016-Desember 2017. Pasien TBI dipindai untuk diagnosis kontusio serebral menggunakan CT scan awal dan adanya pembengkakan jaringan lunak sebagai tempat terjadinya benturan. Lokasi itu kemudian secara geometris diklasifikasikan menjadi empat kelompok; frontal, temporoparietal kanan, temporoparietal kiri, dan oksipital, kemudian dianalisis menggunakan metode regresi logistik multinomial dengan $\alpha=0,05$ dan interval kepercayaan (IK) 95\%. Kontusio temporoparietal kanan dikaitkan dengan impact contrecoup dibanding dengan impact frontal ( $\mathrm{p}=0,008$, OR 6,8, IK 95\% 1,6-28,7) dan impact oksipital ( $\mathrm{p}=0,002$, OR 6,8, IK 95\% 1,7-26,8), sementara kontusi temporoparietal kiri dikaitkan dengan impact contrecoup dibandingkan dengan impact frontal ( $\mathrm{p}=0,006$, OR 6,8, IK 95\% 1,7-26,8) dan impact oksipital ( $\mathrm{p}=0,016$, OR 10, IK 95\% 1,3-17) dan dengan impact coup dibanding dengan impact frontal ( $\mathrm{p}=0,025, \mathrm{OR} 5,3, \mathrm{IK}$ 95\% 1.2-23.3). Simpulan, bahwa kontusio temporal memiliki korelasi yang signifikan secara statistik dengan impact contrecoup.
\end{abstract}

Key words: Cedera otak traumatika; CT scan, impak dari cedera, kontusi serebral

Corresponding Author: Ahmad Faried, Department of Neurosurgery Faculty of Medicine Universitas Padjadjaran/Dr. Hasan Sadikin General Hospital Bandung, Jalan Pasteur No. 38 Bandung, West Java, Indonesia. Email: ahmad.faried@unpad.ac.id 


\section{Introduction}

Traumatic brain injury (TBI) is a major global public health and socioeconomic burden, with at least 2.8 million cases annually in the United States (U.S.) and an even higher number in lowmiddle-income and developing countries, not including undiagnosed mild TBI. ${ }^{1,2}$ In Dr. Hasan Sadikin General Hospital (RSHS) Bandung, the top referral hospital of the most populous province in Indonesia, the number of cases during the period of January 2013 to June 2014 alone has reached $2108 .{ }^{3} \mathrm{TBI}$ is the leading cause of death in a trauma setting.

Cerebral contusion is a common intracranial lesion seen in TBI, which is present in 17-34\% of brain injuries. ${ }^{4,5}$ Impact injury is responsible for this type of lesion, and its inertial effect is found to be more injurious to the brain due to strains and injuries that may occur in any site with no ways of predicting its location without using a computed tomography (CT) scan. Cerebral contusion is also very prone to increased intracranial pressure, emphasizing the importance of close observation and prompt intervention if the condition occurs. This study aimed to identify the relationship between a specific impact location and cerebral contusion location. It is expected that the if the relationship can be established in this study, this approach may be considered to be used to predict location of contusion in health care centers without access to CT scan in order to be able to perform decompression as indicated and to predict clinical deterioration as important information to be conveyed to the patient and their family.

\section{Methods}

Data were collected retrospectively from patients with cerebral contusion in Dr. Hasan Sadikin General Hospital from January 2016 to December 2017. Inclusion criteria was not limited by age, type of head injury, severity, other intracranial lesions, and skull fracture. During the study period, 322 patients were diagnosed with cerebral contusion and 75 patients were excluded from the study for the following reasons; incomplete medical record, no visible soft tissue swelling, or more than one location of soft tissue swelling. Data on patients' age, sex, injury mechanism, initial Glasgow Coma Scale (GCS), pupil reactivity, CT scan interpretation, and early management plan were collected from medical records. For referred patients, data on the initial GCS and CT scan were collected from the previous hospital's data that were submitted during their first visit to RSHS.

Variables considered in this study were the location of soft tissue swelling as the site of impact and the location of cerebral contusion indicated by a 'salt and pepper' appearance. Impact location was first obtained by clinical observation and then confirmed using CT scan. The interpretation of each CT scan was made by four neurosurgical residents and confirmed by at least two senior attendings. The location was named to a specific anatomical location but classified based on the geometric classification by Cepeda, et al. ${ }^{6}$ (Figure): frontal $\left(0-60^{\circ}, 301-360^{\circ}\right)$, left temporoparietal $(61-$ $\left.135^{\circ}\right)$, right temporoparietal $\left(225-300^{\circ}\right)$, and
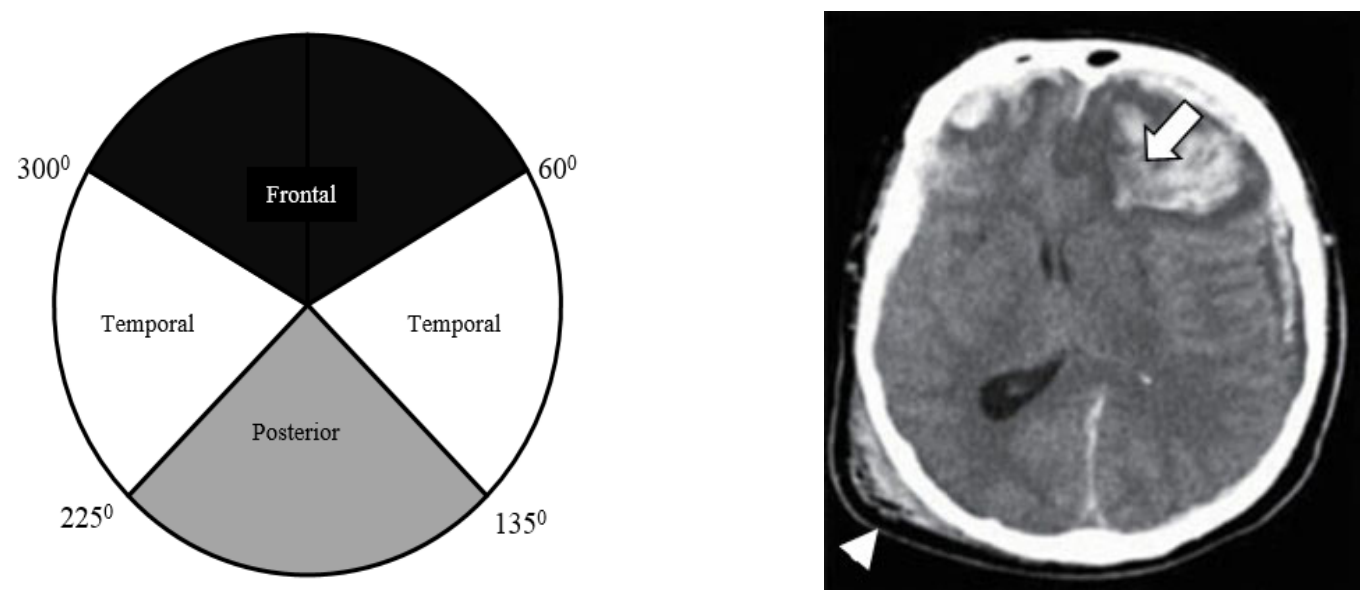

Figure Geometrical Classification (left) for CT Scan Result of Cerebral Contusion (arrow, right panel) and Soft Tissue Swelling or Site of Impact (arrow head, right panel) 
occipital $\left(136-225^{\circ}\right)$. The anatomical location was matched to the geometric classification as follows; (1) frontal: frontal, midfrontal, frontoparietal, frontotemporal in both hemisphere, (2) occipital: occipital, midoccipital, basal ganglia, thalamus, cerebellum, mesencephalon, right and left parietooccipital, (3) temporoparietal: temporal, parietal, temporoparietal, frontotemporoparietal and temporoparietooccipital in both hemispheres.

Multiple contusions will be treated individually, provided that each contusion only had one location of trauma. This method resulted in 279 contusions from 247 patients. Analysis was conducted using the multinomial logistic regression in SPSS version 22.0, as provided by Kandaga unit of Universitas Padjadjaran, with $\alpha=0.05$ and CI 95\%. Permission for data collection has been gained from the Health Research Ethics Committee in Dr. Hasan Sadikin General Hospital with the issuance of the ethical clearance No. LB.02.01/X.2.2.1/14927/2018.

\section{Results}

Of all patients in this study, $74.4 \%$ were involved in road traffic accidents. Male patients of 15-65 years old were predominant in this study with the mean age of 35 (Table 1).

Table 1 Subject Demographic Characteristics

\begin{tabular}{|c|c|c|}
\hline \multirow{2}{*}{ Variable } & \multicolumn{2}{|c|}{ Total } \\
\hline & $n=246$ & $\%$ \\
\hline \multicolumn{3}{|l|}{ Age (years) } \\
\hline$<15$ & 24 & $9 \%$ \\
\hline $15-65$ & 210 & $85.4 \%$ \\
\hline$>65$ & 12 & $4.9 \%$ \\
\hline \multicolumn{3}{|l|}{ Sex } \\
\hline Male & 180 & $73.2 \%$ \\
\hline Female & 66 & $22.8 \%$ \\
\hline \multicolumn{3}{|l|}{ Injury mechanism } \\
\hline Rta $^{*}$ & 183 & $74.4 \%$ \\
\hline Fall & 48 & $19.5 \%$ \\
\hline Others & 15 & $6.1 \%$ \\
\hline \multicolumn{3}{|l|}{ Injury severity } \\
\hline Mild (15-13) & 94 & $38.2 \%$ \\
\hline Moderate (12-9) & 128 & $52 \%$ \\
\hline Severe $(8-3)$ & 24 & $9.8 \%$ \\
\hline \multicolumn{3}{|l|}{ Pupil reactivity } \\
\hline Equal & 218 & $88.3 \%$ \\
\hline Unequal & 28 & $11.3 \%$ \\
\hline \multicolumn{3}{|l|}{ Number of contusion } \\
\hline Single & 219 & $89 \%$ \\
\hline Multiple & 27 & $11 \%$ \\
\hline Other intracranial lesions & 160 & $64.8 \%$ \\
\hline $\mathrm{ICH}^{\mathrm{a}}$ & 55 & $22.4 \%$ \\
\hline $\mathrm{SAH}^{\mathrm{b}}$ & 84 & $34.1 \%$ \\
\hline $\mathrm{EDH}^{\mathrm{c}}$ & 40 & $16.3 \%$ \\
\hline $\mathrm{SDH}^{\mathrm{d}}$ & 71 & $28.9 \%$ \\
\hline Skull fracture & 145 & $58 \%$ \\
\hline \multicolumn{3}{|l|}{ Initial management plan } \\
\hline Close observation & 170 & $69.5 \%$ \\
\hline Surgery & 77 & $31.5 \%$ \\
\hline
\end{tabular}

*RTA; road traffic accident, ${ }^{\mathrm{a} I C H}$; intracerebral hemorrhage, ${ }^{\mathrm{b}} \mathrm{SAH}$; subarachnoid hemorrhage, ${ }^{\mathrm{c} E D H}$; epidural hemorrhage, ${ }^{\mathrm{S} D H}$; subdural hemorrhage 
Karima, et al: Analysis of Geometric Relation between Cerebral Contusion and Site of Impact in Traumatic Brain Injury Patients

Table 2 Distribution of Cerebral Contusion and Soft Tissue Swelling/Impact Site

\begin{tabular}{lccccc}
\hline & \multicolumn{4}{c}{ Site of Soft Tissue Swelling } \\
\cline { 2 - 6 } $\begin{array}{l}\text { Cerebral Contusion } \\
\text { Location }\end{array}$ & Frontal & $\begin{array}{c}\text { Right } \\
\text { temporo-parietal }\end{array}$ & $\begin{array}{c}\text { Left } \\
\text { temporo-parietal }\end{array}$ & Occipital & Total \\
\cline { 2 - 6 } & $\mathbf{n = 8 0}$ & $\mathbf{n = 6 6}$ & $\mathbf{n = 6 6}$ & $\mathbf{n = 6 7}$ & $\mathbf{n = 2 7 9}$ \\
\hline Frontal & $55(38 \%)$ & $25(17 \%)$ & $26(18 \%)$ & $39(27 \%)$ & $145(52 \%)$ \\
$\begin{array}{l}\text { Right } \\
\text { Temporoparietal }\end{array}$ & $7(12 \%)$ & $15(26 \%)$ & $24(42 \%)$ & $11(20 \%)$ & $57(20 \%)$ \\
$\begin{array}{l}\text { Left } \\
\text { Temporoparietal }\end{array}$ & $8(17 \%)$ & $22(47 \%)$ & $11(23 \%)$ & $6(13 \%)$ & $47(17 \%)$ \\
Occipital & $10(33 \%)$ & $4(13 \%)$ & $5(17 \%)$ & $11(37 \%)$ & $30(11 \%)$ \\
Total & $80(28.7 \%)$ & $66(23.6 \%)$ & $66(23.6 \%)$ & $67(24.1 \%)$ & 279 \\
\hline
\end{tabular}

The male to female ratio in this study was $3.2: 1$. More than a half of the patients had a moderate head injury (52\%) with mostly single contusion and $64.8 \%$ patients had other intracranial lesions. Contusions were predominantly observed in the frontal $(52 \%)$ and temporoparietal areas (37\%) as seen in Table 2 . Only $31.5 \%$ had to undergo surgery with the rest were treated conservatively.

Right temporoparietal contusion was found to be associated with left temporal impact (contrecoup) compared to frontal impact $(95 \%$ CI: 1.6-28.7) and occipital impact (95\% CI 2.3-43). Left temporoparietal contusion was significantly associated with right temporal impact (contrecoup) compared to frontal impact $(95 \%$ CI 1,7-26,8) and occipital impact $(95 \%$ CI 1.3-17). Left temporoparietal contusion was also associated with coup impact when compared to frontal impact (95\% CI 1.2-23.2). These values are listed in Table 3.

Table 3 Analysis of Geometric Relation between Cerebral Contusion and Impact Site

\begin{tabular}{|c|c|c|c|c|c|c|c|}
\hline \multirow[t]{3}{*}{ Soft Tissue Swelling } & \multicolumn{7}{|c|}{ Cerebral Contusion } \\
\hline & \multicolumn{2}{|c|}{ Frontal } & \multicolumn{2}{|c|}{$\begin{array}{c}\text { Right } \\
\text { Temporo-parietal }\end{array}$} & \multicolumn{2}{|c|}{$\begin{array}{c}\text { Left } \\
\text { Temporo-parietal }\end{array}$} & \multirow[t]{2}{*}{ Occipital $^{\mathrm{a}}$} \\
\hline & $P$ value & $\mathbf{O R}^{\mathbf{b}}$ & $P$ value & OR & P value & OR & \\
\hline \multicolumn{8}{|l|}{ Ref: frontal } \\
\hline Right temporoparietal & 0.925 & 0.925 & 0.159 & 2.756 & 0.01 & 6.857 & 0 \\
\hline Left temporoparietal & 0.841 & 1.136 & 0.008 & 6.875 & 0.025 & 5,3 & 0 \\
\hline Occipital & 0.365 & 0.645 & 0.581 & 0.682 & 0.584 & 1.429 & 0 \\
\hline \multicolumn{8}{|l|}{ Ref: Right temporoparietal } \\
\hline Frontal & 0.925 & 1.058 & 0.159 & 0.364 & $0.006^{c}$ & 0.146 & 0 \\
\hline Left temporoparietal & 0.800 & 1.202 & 0.231 & 2.500 & 0.741 & 0.781 & 0 \\
\hline Occipital & 0.520 & 0.682 & 0.060 & 0.248 & $0.002^{\mathrm{c}}$ & 0.208 & 0 \\
\hline \multicolumn{8}{|l|}{ Ref: Left temporoparietal } \\
\hline Frontal & 0.841 & 0.880 & $0.008^{\mathrm{c}}$ & 0.145 & $0.025^{c}$ & 0.187 & 0 \\
\hline Right temporoparietal & $0.008^{c}$ & 0.832 & 0.231 & 0.400 & 0.741 & 1.280 & 0 \\
\hline Occipital & 0.374 & 0.567 & $0.002^{\mathrm{c}}$ & 0.099 & 0.061 & 0.267 & 0 \\
\hline \multicolumn{8}{|l|}{ Ref: occipital } \\
\hline Frontal & 0.365 & 1.551 & 0.581 & 0.7 & 0.584 & 0.7 & 0 \\
\hline Right temporoparietal & 0.520 & 1.467 & 0.06 & 4 & 0.016 & 10 & 0 \\
\hline Left temporoparietal & 0.374 & 1.700 & 0.002 & 10 & 0.061 & 3.75 & 0 \\
\hline
\end{tabular}

${ }^{\mathrm{a}}$ This parameter is set to zero; used as a reference value; ${ }^{\mathrm{b}} \mathrm{OR}$; odds ratio; ${ }^{\mathrm{c} T h e s e}$ values are not considered significant because $0 \mathrm{R}<1$ 


\section{Discussion}

This study identified that right temporoparietal contusion had a 6.8 times higher possibility to be caused by contrecoup impact (left lateral impact) than frontal impact and 10 times higher than occipital impact. Left temporoparietal contusion also has a higher possibility of being contrecoup with 6.8 times higher possibility than frontal impact and 10 times higher than occipital impact. Left temporoparietal contusion had a higher chance of being coup by 5.3 times when compared to the frontal impact. Hence, most temporoparietal contusions are produced from contrecoup impacts.

Contrecoup temporal contusions have been previously reported in earlier publications, although the definition of contrecoup used differs. $^{6-8}$ Contrecoup lesions have been described as lesions ranging from $90-270^{\circ}$, $151-210^{\circ}$, and $180^{\circ}$ from the impact location. ${ }^{8-11}$ While no exact definition has been established,it can be agreed that it is a lesion that is not directly beneath the site of impact and, in this study, contrecoup is defined as the lesion opposite of impact. Two main mechanisms are identified as the the reason behind contrecoup injury in this study, namely cavitation and inertial injury. ${ }^{12}$

Cavitation theory describes the contact effect of an impact where impact force would create an area of positive pressure (compression) underneath the site of impact (coup) and negative pressure (tension) opposite to it (contrecoup). ${ }^{13}$ When the brain returns to its normal state, compression may change into tension or vice versa. This transient change in intracranial pressure may injure blood vessels in the brain and create contusions. ${ }^{14}$ However, this does not happen in each site of pressure changes with the chance of an injury correlates greatly with the magnitude of impact. This theory might be accounted for the presence of lesions at the opposite side of impact when the pressure is greater, thus producing a contrecoup lesion. Cavitation is also capable to create gas bubbles in any parts of the brain and, when they collapse, the brain is injured.

The cavitation theory has been tested using various head models to determine pressure from different sites of impact. Using a 3D finite element modelling, Ruan et al. $^{15}$ found that frontal impact causes the highest pressure in its coup site and the occipital impact in its contrecoup site.For temporal impacts, pressure in the coup and contrecoup areas is almost equal. This result is similar to another study by Zhao et al. ${ }^{16}$ using Dartmouth Head Injury Model (DHIM). In Zhao's study, it is concluded that for temporal lesions, the chance of producing lesion is equal for both hemispheres due to the bilaterally simetric nature of the anatomical structure. However, these studies only measured brain responses according to contact effects while the gas bubbles and inertial effects were not yet considered when actually the cerebral contusion occurred due to a combination of forces and numerous other factors that are also contribute to this mechanism. Therefore, it would be unwise to explain the results of the present study data by only using one theory for cerebral contusion.

Another proposed mechanism for contrecoup lesion is the inertial injury. Inertial injury occurs as the brain's response to accelerationdeceleration in trauma, causing shearing and brain tissue straining of different structures with different tissue characteristics. ${ }^{9}$ When the force exceeds brain's tolerance to shearing, injuries may occur. In impact injuries, angular acceleration is said to be most injurious and, due to the head-neck articulation, this mechanism cannot be escaped. ${ }^{17}$ Brain's shear modulus is said to be six times its bulk modulus; therefore, both statements confirm that the brain is generally more susceptible to injuries induced by shearing. ${ }^{18}$ This implies that inertial injury is present in every head trauma and lesions can appear in any part of the brain, which would possibly explain our findings.

In a lateral impact, the brain moves as two independent masses, possibly resulting in different inertial effects experienced by both temporal lobes and lower levels of mass that would lessen the angular acceleration needed to produce a TBI. ${ }^{12}$ The complex structure of the head and different tissue characteristics provide numerous factors that contribute in creating cerebral contusions and probably in the contrecoup area. These other factors might have a greater role in producing a contusion. For instance, the middle fossa housing the temporal brain has numerous protuberances and a rougher surface than the anterior or posterior fossa which might predispose to shearing injuries. ${ }^{9}$ However, to our knowledge, studies on the difference of the inertial response in the temporal brain have not yet been done. Current knowledge only covers the frontal impact and the number of studies in this area is limited due to the high cost and ethical issues. ${ }^{19}$ It is also proposed that the temporalis muscle has an effect on creating this lesion; however no pressure difference in the coup and contrecoup areas was observed 
in two different head models (with and without muscle). ${ }^{15,16}$ Duration of impact also plays a role in intracranial injuries as measured using the Wayne State Tolerance Curve. ${ }^{12}$ One study proposed that longer impact duration correlates with contrecoup injuries. ${ }^{20}$ This variable was not obtained in this study, which warrants further studies and documentations to measure its response to the human brain.

Temporoparietal contusion is found to be associated with contrecoup injuries. This result might be useful to predict the location of impact in a temporoparietal contusion. It is concluded that inertial effects play a great role in temporoparietal lesions although further studies are still needed to better analyze the predominant mechanism and other factors that produce a cerebral contusion in accordance with the impact location. It is expected that the results of this study would be helpful to predict contusion sites and the expected clinical deterioration as an important information for the patient and their family, which is a part of the consent process. Also, by understanding the mechanism and brain response towards injury, a more comprehensive preventive step can be taken to greatly reduce the amount and the burden of TBI.

\section{References}

1. Taylor C, Bell J, Breiding M, Xu L. Traumatic brain injury-related emergency department visits, hospitalizations, and deaths-United States, 2007 And 2013. MMWR Surveill Summ. 2017;66(9):1-16.

2. Monsef Kasmaei V, Asadi P, Zohrevandi B, RaoufMT.Anepidemiologicstudy oftraumatic brain injuries in Emergency Department. Emerg (Tehran). 2015;3(4):141-5.

3. Faried A, Bachani AM, Sendjaja AN, Hung YW, Arifin MZ. Characteristics of moderate and severe traumatic brain injury of motorcycle crashes in Bandung, Indonesia. World Neurosurg. 2017;100:195-200.

4. Joseph B, Friese RS, Sadoun M, Aziz H, Kulvatunyou N, Pandit V, et al. The BIG (brain injury guidelines) project: defining the management of traumatic brain injury by acute care surgeons. J Trauma Acute Care Surg. 2014;76(4):965-9.

5. Andriessen TMJC, Horn J, Franschman G, Van Der Naalt J, Haitsma I, Jacobs B, Et Al. Epidemiology, severity classification, and outcome of moderate and severe traumatic brain injury: a prospective multicenter study. J Neurotrauma . 2011;28(10):2019-31.

6. Cepeda S, Gómez PA, Castaño-Leon AM, Munarriz PM,Paredes I,LagaresA.Contrecoup traumatic intracerebral hemorrhage: a geometric study of the impact site and association with hemorrhagic progression. J Neurotrauma . 2016;33(11):1034-46.

7. Bešenski N. Traumatic injuries: imaging of head injuries. Eur Radiol . 2002;12(6):123752.

8. Renganathan R, Paul PJ, Anandan H. A Comprehensive study on post traumatic temporal contusion in adults. 2017;5(3):306-10.

9. Winn HR. Youmans and winn neurological surgery. 7th Ed. US: Elsevier; 2016.

10. Ommaya AK, Grubb RL, Naumann RA. Coup and contre-coup injury: observations on the mechanics of visible brain injuries in the rhesus monkey. J Neurosurg. 1971;35(5): 503-16.

11. Bešenski N, Broz R, Jadro-Šantel D, Pavić D, Mikulić D. The course of the traumatising force in acceleration head injury: ct evidence. Neuroradiology. 1996;38(Suppl 1):41-6.

12. Young L, Rule GT, Bocchieri RT, Walilko TJ, Burns JM, Ling G. When physics meets biology: low and high-velocity penetration, blunt impact, and blast injuries to the brain. Front Neurol. 2015;6:1-13.

13. Pearce CW, Young PG. On the pressure response in the brain due to short duration blunt impacts. Plos One. 2014;9(12):1-13.

14. Zhang L, Yang KH, King AI. A proposed injury threshold for mild traumatic brain injury. J Biomech Eng . 2004;126(2):226.

15. Ruan JS, Khalil T, King AI. Dynamic response of the human head to impact by threedimensional finite element analysis. J Biomech Eng . 1994;116(1):44.

16. Zhao W, Ruan S, Ji S. Brain pressure responses in translational head impact: a dimensional analysis and a further computational study. Biomech Model Mechanobiol. 2015; 14(4):753-66.

17. Post A, Hoshizaki TB. Mechanisms of brain impact injuries and their prediction: a review. Trauma. 2012;14(4):327-49.

18. Barth JT, Freeman JR, Broshek DK, Varney RN. Acceleration-deceleration sport-related concussion: the gravity of it all. J Athl Train. 2013;36(3):253-6.

19. Sabet AA, Christoforou E, Zatlin B, Genin GM, Bayly P V. Deformation of the human brain induced by mild angular head acceleration. J 
Biomech. 2008;41(2):307-15.

20. Aomura S, Zhang Y, Fujiwara S, Nishimura A. Dynamic analysis of cerebral contusion under impact loading. J Biomech Sci Eng. 2008;3(4):499-509. 